\title{
Ulasan Bunga Rampai Gubahan Akademisi Manajemen \& Akuntansi 2019
}

\author{
Berliana Puspitasari \\ Universitas Nahdlatul Ulama Sidoarjo
}

\section{A. Pendahuluan}

Universitas Bahaudin Mudhary Madura (UNIBA Madura) yang terletak di kota Sumenep pada tahun 2019 menugaskan seluruh dosen tetap untuk menyusun tulisan dalam dua bunga rampai (bookchapter). Ulasan sederhana ini bertujuan guna memberikan resensi singkat terhadap pemikiran-pemikiran yang termaktub didalam bookchapter karya putri-putri Madura tersebut.

\section{B. Bunga Rampai Gubahan Akademisi Manajemen 2019}

\begin{tabular}{|l|l|}
\hline Identitas Buku & Keterangan \\
\hline Judul Buku & Bunga Rampai Gubahan Akademisi Manajemen 2019 \\
\hline Penulis & $\begin{array}{l}\text { Alvin Arifin, Ach. Zuhri, Humera Asad Ullah Khan, } \\
\text { Mahmud Yunus }\end{array}$ \\
\hline Gaya penulisan & Ilmiah \\
\hline Penerbit & STIEBA Madura Press \\
\hline Tahun & 2019 \\
\hline ISBN & $978-623-7385-02-8$ \\
\hline Jumlah halaman & 54 \\
\hline
\end{tabular}

Gagasan Mahmud Yunus tentang "Bagaimana Kepemimpinan Bekerja di dalam Organisasi" mengulas tentang tugas utama pemimpin untuk pengambilan keputusan atas segala sesuatu yang terjadi dalam organisasi karena sudah diputuskan. Semakin tinggi posisi seseorang dalam organisasi, semakin besar bobot keputusannya (Yunus, 2019).

Peneliti bernama Ach. Zuhri dengan tulisan berjudul "VUCA (- \& +) Kepemimpinan Wirausaha Era Disrupsi Digital" mengajak kita untuk mengulas cara mengatasi disrupsi kepemimpinan dengan cara seorang pemimpin bisa mengelola dirinya dan bisnisnya menggunakan pendekatan VUCA (Vision, Undertanding, Clarity, Awareness) (Zuhri, 2019).

Tulisan bertajuk "Manajemen Sumber Daya Manusia pada Masyarakat Desa" karya penulis Alvin Arifin mengulas tentang penciptakan inisiatif masyarakat dan edukasi serta sosialisasi menyeluruh kepada masyarakat setempat bagaimana mengembangkan desa. Peran aktif masyarakat yang disertai dukungan pemerintah akan memotivasi masyarakat untuk mengembangkan desanya (Arifin, 2019).

Perenungan bertajuk "Tantangan dalam Manajemen Pemasaran" hasil pemikiran Humera Asad Ullah Khan bercerita tentang tantangan para tenaga 
pemasaran yang menghadapi perubahan konsisten, ada banyak teknik yang harus dipelajari, banyak kasus yang harus dipelajari, dan strategi sampai penelitian. Kita dapat memperoleh pengalaman dunia pemasaran di karir yang anda pilih dengan ikut serta untuk magang atau bekerja sukarela di pengabdian kepada masyarakat (Khan, 2019).

\section{Bunga Rampai Gubahan Akademisi Akuntansi 2019}

\begin{tabular}{|l|l|}
\hline Identitas Buku & Keterangan \\
\hline Judul Buku & Bunga Rampai Gubahan Akademisi Akuntansi 2019 \\
\hline Penulis & $\begin{array}{l}\text { Kartika Rusnindita, Subaida, Liahmad, Nadiyah } \\
\text { Masithah Sani, Istiyanatul Mahbubah }\end{array}$ \\
\hline Gaya penulisan & Ilmiah \\
\hline Penerbit & STIEBA Madura Press \\
\hline Tahun & 2019 \\
\hline ISBN & $978-623-7385-01-1$ \\
\hline Jumlah halaman & 75 \\
\hline
\end{tabular}

Perenungan berjudul "Teori Akuntansi: Pengertian, Peran, Praktik, Asumsi dan Metode" hasil perenungan peneliti Liahmad menelusuri tentang teori akuntansi yang terus berkembang dan tumbuh serta memerlukan pemahaman menyeluruh (Liahmad, 2019).

Peneliti Istiyanatul Mahbubah dengan tulisan bertajuk "Peran E-Commerce Terhadap Peningkatan Pendapatan Usaha Mikro Kecil dan Menengah” mengajak kita untuk memahami E-commerce untuk mengembangkan lingkungan usaha yang kondusif bagi usaha mikro, kecil dan menengah agar tumbuh baik dan produktif (Mahbubah, 2019).

Tulisan bertajuk "Studi Fenomena Partisipasi Anggaran, Komitmen Organisasi serta Asimetri Informasi yang Berpotensi Terjadinya Senjangan Anggaran" karya penulis Kartika Rusnindita mengulas tentang perlunya suatu komitmen berkesinambungan yang jelas antara partisipasi anggaran, komitmen organisasi, adanya simetri informasi yang baik agar tidak terjadi senjangan anggaran. (Rusnindita, 2019).

Ulasan bertajuk "Mengenal Fraud: Bentuk dan Ciri-Cirinya" hasil pemikiran Subaida bercerita mengenai tindakan fraud sangat berbahaya terhadap sebuah perusahan karena dapat merugikan pihak perusahan. Ciri-ciri fraud ada lima yaitu memiliki jabatan penting atau bagian financial, gaya hidup mewah, memiliki kesulitan ekonomi, sering bekerja lembur dan suka bekerja sendiri (Subaida, 2019).

Gagasan Nadiyah Masithah Sani mengenai "Sudut Pandang Etika dan Moral Korupsi dari Perspektif Akuntansi" mengulas tentang korupsi dapat berdampak negatif terhadap moral, citra buruk, merusak tatanan, kehilangan akuntabilitas (Sani, 2019). 


\section{Penutup}

Tulis pemikiran buku bunga rampai bertajuk Bunga Rampai Gubahan Akademisi Akuntansi 2019" dan "Bunga Rampai Gubahan Akademisi Akuntansi 2019" cukup menarik untuk dibaca dan dipelajari untuk memperkaya wawasan kita di area bidang akuntansi dan manajemen.

\section{References}

Arifin, A. (2019). Manajemen Sumber Daya Manusia pada Masyarakat Desa. In Bunga Rampai Gubahan Akademisi Manajemen 2019. Sumenep: STIEBA Madura Press.

Khan, H. A. U. (2019). Tantangan dalam Manajemen Pemasaran. In Bunga Rampai Gubahan Akademisi Manajemen 2019. Sumenep: STIEBA Madura Press.

Liahmad. (2019). Teori Akuntansi: Pengertian, Peran, Praktik, Asumsi dan Metode. In Bunga Rampai Gubahan Akademisi Akuntansi 2019. Sumenep: STIEBA Madura Press.

Mahbubah, I. (2019). Peran E-Commerce Terhadap Peningkatan Pendapatan Usaha Mikro Kecil dan Menengah. In Bunga Rampai Gubahan Akademisi Akuntansi 2019. Sumenep: STIEBA Madura Press.

Rusnindita, K. (2019). Studi Fenomena Partisipasi Anggaran, Komitmen Organisasi serta Asimetri Informasi yang Berpotensi Terjadinya Senjangan Anggaran. In Bunga Rampai Gubahan Akademisi Akuntansi 2019. Sumenep: STIEBA Madura Press.

Sani, N. M. (2019). Sudut Pandang Etika dan Moral Korupsi dari Perspektif Akuntansi. In Bunga Rampai Gubahan Akademisi Akuntansi 2019. Sumenep: STIEBA Madura Press.

Subaida. (2019). Mengenal Fraud: Bentuk dan Ciri-Cirinya. In Bunga Rampai Gubahan Akademisi Akuntansi 2019. Sumenep: STIEBA Madura Press.

Yunus, M. (2019). Bagaimana Kepemimpinan Bekerja di Dalam Organisasi. In Bunga Rampai Gubahan Akademisi Manajemen 2019. Sumenep: STIEBA Madura Press.

Zuhri, A. (2019). VUCA (- \& +) Kepemimpinan Wirausaha Era Disrupsi Digital. In Bunga Rampai Gubahan Akademisi Manajemen 2019. Sumenep: STIEBA Madura Press. 